SECTION 21. Pedagogy. Psychology. Innovations in the field of education.

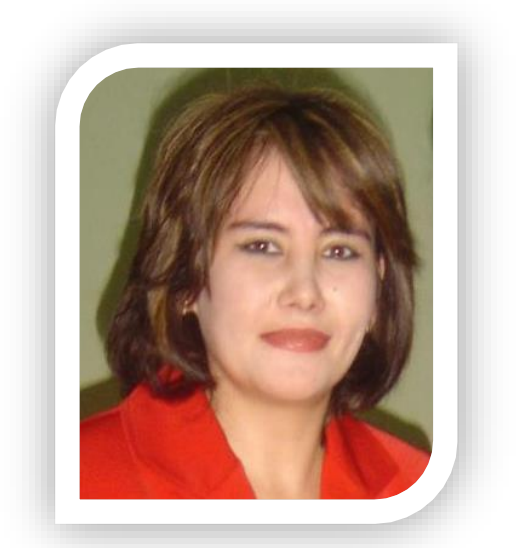

\author{
Sanobar Narzikulovna Akbarova \\ assistant, candidate of psychological sciences, \\ Tashkent Pediatric Medical institute, \\ Uzbekistan \\ sanobarakbarova@tashpmi.uz
}

\title{
HEREDITY REGULARITY OF PSYCHOLOGICAL PROPERTIES OF PERSON
}

Abstract: The article deals with regularity inheritance for psychological properties of personal being found in the course of study relationship for dermatoglifics with typical features of person and its use in genetic psychology. The principle of study nature of psychological properties origin was shown on the example of aggression's study.

Key words: heredity, regularity, dermatoglific, properties of character, person, genetic psychology

The problem of "nature-education"correlation is considered as an actual of psychological sciences and it is studied in a wide range on the chapter in genetic psychology. Determination of the environment relative contribution and genetics on individual psychological differences, is considered as a task of psychogenetics [1, pp. 160].

Person is perceived as an integral biologically and socially conditioned human [2, p.27]. This is also another theory of V.Shtern about convergence of two factors [4, p.16]. Despite this, there is still some scientists underestimate the role of genetic factors in the psyche of the individual. For example, A.V.Osnitskiyning believes that "personality traits can not be genetically programmed" [5, P.77]. He explains his position with "modern inheritance theory of psychological and psychopathological symptoms by transferring genetic information have not reliable data on the actual mechanism of inheritance, and, have the character of hypotheses" [10, P.86]. Such situation could lead to further discussions of main methodological issues - "nature-education". The solution of such problems can be done by finding new regularity, i.e. by opening of constantly repeating regularity for different cases. One of these regularities is the "Heredity of psychological properties (S.N.Akbarova, 2007) [7, p.16]:

\section{"The gradual trend of increasing or reduction of frequency occurrence for certain dermatoglyphics features in groups, where the researching psychological property is expressed in ascending or descending order, and it proves that the studied psychological property has a genetic basis."}

Dermatoglyphics - ("derma" - leather, "glyphe" - carving patterns) is scientific direction is study papillary lines on the palm $[8, p .3]$, it is an external reflection of genotype phenotypic trait.

Basing on above mentioned regularity we can explore the origin nature of any psychological characteristics for personality. In order to do this we must create several groups of people, where they differ by the severity of psychological properties. Minimum number of people should be 10 in the group. For example, in one of our studies we examined aggression. 
508 participants (female) senior classes were examined at schools in Tashkent City. The Expert evaluation questionnaire (EEQ) was taken, where experts were a parent, tutor and a classmate of tested objects. Questions on the questionnaire were:

1) His expressed aggression at a high level

2) His expressed aggression at an average level

3) His expressed aggression at a little level

4) Without aggression

From 508 students studied, we have identified only those whose evaluation were the same. So, we got 21 girls being estimated by level 1 (group 1), 35 girls - with an average level of aggressiveness (group 2), 22 girls were in group 3 (group 3), 21 girls were without aggression (group 4 ). As we can see, these groups are composed in such way that they have the aggression quality is expressed by decreasing trend. 1 - group represents a high level of aggression and 4-group of respondents is not aggressive. Then, the data of individuals' handprints of these four groups were comparatively studied. The result marked the trend of increasing or decreasing the amount of occurrence dermatoglific signs in these groups. For example we give the variation of occurrence frequency of the end for the main line $\mathrm{D}$ on the left hand (table 1).

Table 1.

The end of a main line $D$ on the left arm.

\begin{tabular}{|l|l|l|l|l|l|l|l|}
\hline \multirow{2}{*}{ Group } & \multicolumn{7}{|c|}{ The end of D line \% } \\
\cline { 2 - 8 } & Field 7 & Field 11/7 & Field 8 & Field 9/7 & Field 9 & Field 10 & Field 11 \\
\hline 1 & 28,5 & - & 4,7 & - & $\mathbf{3 8}$ & 4,7 & 23,8 \\
\hline 2 & 25,7 & - & - & 2,8 & $\mathbf{2 8 , 5}$ & 5,7 & 37,1 \\
\hline 3 & 22,7 & - & - & 13,6 & $\mathbf{2 7 , 2}$ & 4,5 & 31,8 \\
\hline 4 & 47,6 & - & - & - & $\mathbf{1 9}$ & 9,5 & 23,6 \\
\hline
\end{tabular}

As we see, the characteristic frequency of D (9) in the group is composed by descending aggression have trends to be considerable reduction. If we compare 1 - group with 4-group, we obtain $\mathrm{P}<0,1$ and this situation proves that aggression has the significant genetic basis [6, P.104]. For study hereditary of psychological properties it is very important to research dermatoglyphics mainly in the several groups (minimum of 3 groups), where psychological properties are manifested in the degree of increase or decrease. Only in at such way it can be exactly proved that the property has hereditary basis in some degree or not. Any psychological property, if there is a hereditary characteristics is reflected in the dermatoglyphics (including lines and patterns of the foot) for the above mentioned regularities. The level of these reflections and questions of clarify percentage of genetic and social effects on each individual must be examined separately. When we put the question, for example, "whether hereditary traits are genetically predetermined?", we must immediately clarify exactly what kind of particular trait in question. Mental properties can be divided into 3 categories: having a strong influence of genetics, moderate genetic basis and hardly any genetic foundation. For example, in our previous studies the traits manifestation of bravery in dermatoglyphics showed $\mathrm{P}<0,01$ [9, p.70]. It tells about the high role of genes in reflection of courage. Also, it always must be taken into account how many dermatoglific signs were associated with the studied property. Table 1 shows only one sign, but aggression is also connected with other signs of dermatoglyphics [6, P.104]. If a mental property has a significant relationship with a lot of dermatoglyphic features it says that this property is under the influence of large genes numbers.

Till today, there were attempts to prove the existence of links between dermatoglyphics and psychological properties, but it shows dermatoglific differences only in the two groups. This efficiency of these method is explained with "true" differences in these 
two groups may be occasional. "Inheritance regularity of psychological properties" to put an end to all doubts and occasions, and, it can objectively answer the question of genetically determination of the properties.

Our further objectives are to study the reverse principle of inheritance regularity for psychological personality traits, where the group will be made up by dermatoglyphic features. We are interested in question how to express certain mental property in groups where one of the signs in dermatoglyphic complex is constantly decreasing? Clarification of this issue also gives the opportunity of comprehensive study relationship of dermatoglifics and mental properties.

Analyzing researches concerning to dermatoglific, it is possible to draw following conclusions: dermatoglific should take a special place in studying of psychological properties' origin, in particular in the field of psychogenetics. Because dermatoglific is an original reflexion of genetic code of the person. It is unique also that it does not vary during human life. Even after any traumas dermatoglific' signs are restored without change. Therefore dermatoglific is studied in medicine area, especially in psychiatry too, in connection with hereditary diseases. There are many literary given showing such communications. All it shows originality of dermatoglific in the aspect of genetics.

Summing up on the stated judgments, heredity regularity of psychological properties can be recommended in a wide range of human nature's investigation where property can vary in various degrees. It can be a reliable basis for the further opening in the field of psychology.

\section{Bibliography:}

1. Дружинин В.Н. Экспериментальная психология: Учебник для вузов. -2- е изд., доп. - СПб.: Питер, 2005. -319 с.

2. Психология: Учебник / Аллахвердов В.М., Богданова С.И. идр.; Отв. ред. Крылов А.А. 2-е изд., перераб. и доп. - М.: ТК Велби, Изд-во Проспект, 2004. -752 с.

3. Психология: Учебник для пед-ких вузов / Под ред. Сосновский Б.А. - М.: Юрайт- Издат, 2005. - 660 с.

4. Бойко Е.М., Садовникова Е.А. Психология и педагогика: Учеб. пособие. - М.: РИОР, 2005. $-108 \mathrm{c}$.

5. Осницкий А.В. Теоретические основы наследственности психических свойств личности // Научно-теоретический журнал «Ученые записки». 2008. №5(39). С.77-80

6. Акбарова С.Н., Чистякова.А.А. Наследственное отражение предпосылок агрессивности человека // Новый университет. 2014. №01(34). С.102-104.

7. Акбарова.С.Н. Шахс характерининг конституционал-психологик жихатлари: психол. фан.ном. дис. Автореферат // С.Н.Акбарова - Тошкент: Низомий номли ТДПУ, 2007.-21

8. Залетаева Т.А. Дерматоглифика как метод исследования в медицинской генетике. -М.: ЦОЛИУВ, 1976. -41с.

9. Якубова С.Н. Мардлик хусусиятининг келиб чиқиши // Халқ таълими. Тошкент, 2003. -№ 6. -Б. 69-71.

10. Осницкий.А.В. Психологические основы наследственности личностных свойств // Известия Российского Государственного Педагогического университета им.А.И.Герцена, № 57, 2008, С. 86-96. 